\title{
Incidence of Tetracycline and Erythromycin Resistance in Meat-Associated Bacteria: Impact of Different Livestock Management Strategies
}

\author{
Cecilia Fontana ${ }^{1,2}$, Vania Patrone ${ }^{3}(\mathbb{D})$, Constanza Maria Lopez ${ }^{1}$, Lorenzo Morelli ${ }^{1,3}$ and Annalisa Rebecchi ${ }^{1,3, *(D)}$ \\ 1 Biotechnology Research Centre (CRB), Università Cattolica del Sacro Cuore, Via Milano 24, \\ 2610 Cremona, Italy; cecilia.fontana@unicatt.it (C.F.); constanzamaria.lopez@unicatt.it (C.M.L.); \\ lorenzo.morelli@unicatt.it (L.M.) \\ 2 INTA EEA Famaillá, Tucumán 4172, Argentina \\ 3 DISTAS, Università Cattolica del Sacro Cuore, Via Emilia Parmense 84, 29100 Piacenza, Italy; \\ vania.patrone@unicatt.it \\ * Correspondence: annalisa.rebecchi@unicatt.it
}

Citation: Fontana, C.; Patrone, V.; Lopez, C.M.; Morelli, L.; Rebecchi, A. Incidence of Tetracycline and Erythromycin Resistance in Meat-Associated Bacteria: Impact of Different Livestock Management Strategies. Microorganisms 2021, 9 2111. https://doi.org/10.3390/ microorganisms 9102111

Academic Editors: Paul Plummer, Derek Foster and

David Rodríguez-Lázaro

Received: 7 September 2021

Accepted: 1 October 2021

Published: 7 October 2021

Publisher's Note: MDPI stays neutral with regard to jurisdictional claims in published maps and institutional affiliations.

Copyright: (C) 2021 by the authors Licensee MDPI, Basel, Switzerland. This article is an open access article distributed under the terms and conditions of the Creative Commons Attribution (CC BY) license (https:/ / creativecommons.org/licenses/by/ $4.0 /)$.

\begin{abstract}
The extensive use of antibiotics as growth promoters, or their continued abusive misuse to cure or prevent the onset of bacterial infections as occurs in the intensive farming, may have played a pivotal role in the spread of reservoirs of antibiotic resistance (AR) among food-associated bacteria including pathogens representing risks to human health. The present study compares the incidence of tetracycline and erythromycin resistances in lactic acid bacteria (LAB) and coagulase negative staphylococci (CNS) from fermented products manufacturing using meat from intensive animal husbandry (industrialized manufacturing Italian salami) and from extensive farms (artisanal sausages facilities pork and llama Argentinean sausages). A higher incidence of tetracycline resistance (TET-R) compared to erythromycin resistance (ERY-R) was observed among the 205 isolates. Unlike CNS strains, the LAB showed a significant correlation between the TET-R and the ERY-R phenotypes. Genotypic assessment shows a high correlation with tet $\mathrm{K}$ and tet $\mathrm{M}$ for the TET-R strains and with erm B and erm C for the ERY-R strains. Multiple correspondence analyses have highlighted the association between AR phenotypes and CNS species isolated from Italian salami, while the susceptible phenotypes were associated with the LAB species from Argentinean sausages. Since antibiotic resistance in meat-associated bacteria is a very complex phenomenon, the assessment of bacterial resistance in different environmental contexts with diverse farming practices and food production technologies will help in monitoring the factors influencing AR emergence and spread in animal production.
\end{abstract}

Keywords: antibiotic resistance; lactic acid bacteria; coagulase negative staphylococci; animal husbandry; pork and llama meat

\section{Introduction}

Intrinsic and acquired resistance to antibiotics have been described among bacteria; the former has minimal potential for horizontal spread. Acquired resistance, however, as a consequence of the acquisition of genetic material, such as a plasmid or a transposon coding for antibiotic-resistant genes, is potentially transferable, which represents a risk of spreading from one bacterium to another through several mechanisms [1].

Many studies have reported acquired resistance to erythromycin and tetracycline among lactic acid bacteria (LAB) and coagulase negative staphylococci (CNS), and therefore, their corresponding genetic determinants are considered an important potential cause of the horizontal spread of antibiotic-resistant (AR) genes between different bacterial species [2,3].

The improper use of antimicrobial drugs in animal husbandry-mainly tetracycline and erythromycin - has contribute to an increase in AR bacteria in animal food 
products [4,5]. Gevers et al. [6] reported a high incidence of tetracycline-resistant LAB in different types of commercial modified atmosphere-packed fermented dry Belgian sausages and showed that this population was dominated by Latilactobacillus sakei, Companilactobacillus alimentarius and Lactiplantibacillus plantarum species [7]. An analysis of slightly fermented Spanish sausages (chorizo, fuet and salchichon) revealed low percentages of tetracycline and chloramphenicol-resistant isolates of L. sakei, Latilactobacillus curvatus and Leuconostoc mesenteroides [8], while high frequencies of resistant isolates were found against gentamicin and ampicillin. Low levels of resistance to tetracycline and clindamycin were detected in Lactobacillus spp. From dry-cured Spanish sausages as well [9]. Lactobacilli from a traditional Italian salami (Ciauscolo) displayed a high level of resistance to aminoglycosides such as streptomycin and gentamicin, while resistance to tetracycline varied according to the species [10]. Zonenschain et al. [11] reported high erythromycin resistance among lactobacilli isolated from Italian sausages. On the other hand, in fermented llama meat sausages produced in Argentina, L. sakei showed high susceptibility to erythromycin, tetracycline, clindamycin, gentamicin and ampicillin [12].

With regard to antibiotic resistance genes, the most commonly detected in LAB isolates recovered from fermented sausages are tet $\mathrm{M}$ for tetracycline and erm $\mathrm{B}$ for erythromycin resistance $[10,11,13]$.

Several studies regarding CNS have reported the occurrence of AR strains among starter cultures associated with fermented foodstuffs including meat, namely S. carnosus and S. xylosus. Marty et al. [14] investigated the AR of strains from traditionally fermented Swiss sausages. Resistance to penicillin and tetracycline was common in S. xylosus and was associated with the occurrence of blaZ and tetK genes, respectively; the species displaying the lower levels of resistance were S. carnosus and S. equorum [14]. Nunes et al. [15] detected resistance to vancomycin and to methicillin in $47 \%$ and $53 \%$, respectively, of CNS isolated from Brazilian salami, including S. xylosus, Staphylococcus succinus, and S. saprophyticus. Simeoni et al. [16] reported the prevalence of tetK, tet $M$ and erm $C$ genes in resistant staphylococci isolated from the whole swine production chain in Italy. Rebecchi et al. [17] reported the high frequency of tetracycline and erythromycin resistance in CNS isolated from Italian salami production chain, with $e r m \mathrm{C}$, tet $\mathrm{K}$ and tet $\mathrm{L}$ as the most frequently detected AR genes. However, the authors found a strong reduction in AR strains in the final product, suggesting that the manufacturing process may contribute to the reduction in AR bacteria. Very recently, the phenotypic and genotypic AR profiles of CNS from Argentinean artisanal llama sausages were investigated [18]; as a result, a high incidence of resistance to oxacillin, ampicillin and erythromycin followed by tetracycline, kanamycin and gentamicin was shown. BlaZ and tetK were found in all the ampicillin-resistant and tetracycline-resistant strains, respectively, while the mecA gene was only detected in half of oxacillin-resistant CNS.

As summarized in the previous sentences, AR LAB and CNS have been found to be present in processed meat, with some differences tentatively related to the production technology, ripening period, the origin and kind of meat, the geographical location and the management of the farm. In this context, as stated by the FAO [19], intensive farming practices may have an important impact on the increase in resistance to antimicrobials since they have been associated as prophylaxis against infectious diseases, often for prolonged periods and for large populations of animals. On the contrary, extensive livestock farming systems, characterized by low productivity per animal and per surface, appear to only use antimicrobials for the treatment of infected or sick animals rather than for disease prevention or growth promotion. In addition to different livestock management strategies, the safety characteristics of the final microbiota of a fermented meat product can be influenced by other different factors, such as the microbial contamination of raw meat, the ingredients used, and the processing technology [20,21]. The aim of this present study was therefore to investigate the incidence and spread of tetracycline and erythromycin resistance in $\mathrm{LAB}$, and CNS species isolated from meat products coming from two contrasting environments: Italy with intensive breeding practices and industrialized manufacturing; and Argentina 
with rearing extensive and artisanal sausages facilities. For this purpose, a very peculiar family of products such as those manufactured with llama meat were also included. The potential correlations between the occurrence of AR bacteria in these food items and their country of origin, animal husbandry management as well as the manufacturing practices were also investigated.

\section{Material and Methods}

\subsection{Bacterial Strains and Culture Conditions}

A total of $121 \mathrm{LAB}$ and 84 CNS strains included in this study were previously isolated from Italian Piacentino Salami DOP [11,22] and from fermented pork and llama meat produced in Argentina [12,18,23].

The strains were typified by randomly amplified polymorphic DNA (RAPD) technique and taxonomically identified by means of 16S RNA gene sequencing as belonging to Latilactobacillus (L.) sakei, Lactiplantibacillus (L.) plantarum, Staphylococcus xylosus, Staphylococcus equorum and Staphylococcus saprophyticus $[13,14,20,24,25]$. The Italian products were manufactured using meat from intensive swine production facilities, while the Argentinean fermented sausages were produced employing pork and llama meat obtained from animals raised on small rural-hub farms. Moreover, the llama breeding activities were located at $4320 \mathrm{~m}$ above sea level in the province of Jujuy, northwestern Argentina, under conditions of extensive pasture characterized by the grassland varieties typical of the Andean region and without any other breeding activity in the area.

The Italian and Argentinean sausages were produced without the use of starter cultures and their respective formulations and production processes were described by Zonenschain et al. [11] and Fontana et al. [12,23], respectively. Briefly, the Italian sausages were prepared according to the traditional technique using pork meat $(75 \%)$ and lard $(25 \%)$, salt $(2.5 \%)$, black pepper $(0.4 \%)$, white wine $(0.5 \%)$, crushed garlic $(0.2 \%)$, nitrate and ascorbic acid. The Argentinean pork and llama sausages were prepared mixing pork meat $(85 \%)$ or llama meat $(75 \%$ and $71.5 \%)$, respectively, with pork fat (between $10 \%$ and $25 \%)$, sodium chloride $(2.6 \%$ and $2.4 \%)$, sugarcane $(0.4 \%$ and $1.0 \%)$, binding and flavoring additives and nitrite/nitrate.

L. sakei and L. plantarum strains were grown at $37^{\circ} \mathrm{C}$ in a $\mathrm{CO}_{2}$-enriched atmosphere on an MRS (Oxoid, Italy) medium. The Staphylococcus $(S)$ strains were cultured in BHI (Brain Heart Infusion, Oxoid) medium under aerobic conditions. Bacterial strains were stored at $-80{ }^{\circ} \mathrm{C}$ in the appropriate broth supplemented with $20 \%$ glycerol [26].

\subsection{Antibiotic Resistance and Determination of the Minimum Inhibitory Concentration}

Resistance to relevant antibiotics has been already demonstrated for the bacterial strains under investigation as previously reported [11,12,18,22]. In this study, the same reference methods were used to assess the susceptibility to tetracycline and erythromycin of all L. sakei and L. plantarum and CNS isolates, in order to ensure a uniform approach and allow data comparison. The minimum inhibitory concentration (MIC) $(\mu \mathrm{g} / \mathrm{mL})$ of the tested antibiotics was reached by the broth microdilution test method using a U-bottom 96-well microtiter plate recommended by the International Organization of Standardization/International Dairy Federation ISO10932/IDF233 standard [24] (for LAB) and CLSI [25] (for Staphylococcus spp.). Briefly, the bacterial inocula were prepared by suspending a single bacteria colony in $3 \mathrm{~mL}$ sterile $0.85 \% \mathrm{NaCl}$ and adjusting the turbidity of the cells' suspension to 1 (for L. sakei and L. plantarum) and 0.5 (for Staphylococcus) with McFarland standard equivalents. The bacterial suspension was diluted 500 and 100 times for L. sakei and L. plantarum, and staphylococci, respectively, in the recommended culture media. LSM broth (90\% w/v Iso-sensitest broth and 10\% MRS) pH 6.7 [26] was used for L. sakei and L. plantarum, while a cation-adjusted Mueller-Hinton broth (CAMHB) was used for the CNS isolates. The different antibiotics' concentration ranges are shown in Table 1. 
Table 1. Antibiotics used, range of concentrations $(\mu \mathrm{g} / \mathrm{mL})$ for MIC determination, and breakpoint values.

\begin{tabular}{cccccc}
\hline Antibiotic & $\begin{array}{c}\text { Range of Concentration } \\
(\mu \mathbf{g} / \mathbf{m L})\end{array}$ & \multicolumn{3}{c}{ MIC Breakpoint $(\boldsymbol{\mu g} / \mathbf{m L})$} \\
\hline & LAB & CNS & L. sakei & L. plantarum & CNS \\
\hline Tetracycline & $4-512$ & $4-256$ & $>8$ & $>32$ & $\geq 16$ \\
Erythromycin & $0.25-512$ & $4-256$ & $>1$ & $>1$ & $\geq 8$ \\
\hline
\end{tabular}

L. sakei and L. plantarum: MIC breakpoint [27] CNS: MIC breakpoint [25].

Tetracycline and erythromycin (Sigma, St. Louis, MO, USA) were diluted in a LSM or CAMHB medium in the appropriate concentration. Fifty microliters of the two-fold concentration of antibiotic solutions were dispensed into a well and the microplates were subsequently inoculated with $50 \mu \mathrm{L}$ of the cell suspension and incubated for $48 \mathrm{~h}$ at $30^{\circ} \mathrm{C}$ under anaerobic conditions (Anaerocult, Darmstadt, Germany) for L. sakei and L. plantarum, and for $24 \mathrm{~h}$ at $37^{\circ} \mathrm{C}$ under aerobic conditions for Staphylococcus. All experiments were performed in duplicate. The bacterial growth was measured as the cell density in the well bottom and compared to the growth in the control well containing the growth medium without antibiotics. L. plantarum LMG6907 and S. aureus ATCC29213 were used as quality control strains. The MIC value was defined as the lowest concentration of antibiotic with no visible growth in the microtiter well. Results of the tetracycline and erythromycin susceptibility assessment were interpreted according to the guidelines of the European Food Safety Authority [27] for L. sakei and L. plantarum, and CLSI [25] for Staphylococcus. The MIC breakpoints are reported in Table 1.

\subsection{Detection of Antimicrobial Resistance Genes}

DNA extraction from bacterial cultures was performed using the Microlysis solution (LABOGEN, UK) according to the protocol described by the manufacturer. The PCR amplification of the structural genes associated with TET and ERY resistance was performed using the primers and conditions listed in Table S1.

\subsection{Statistical Analyses}

Pearson's correlation was used to analyze the association between phenotypic and genotypic features; $p$-values $<0.05$ were considered statistically significant.

A contingency table was used to evaluate the relationship between the phenotypic antibiotic resistance (MIC values) and gene incidence. The Chi-square test $(p<0.05)$ was performed, and Pearson's contingency coefficient was calculated to determine the weight and the significance of the association.

A logistic regression model was used to evaluate the association of TET and ERY phenotypic resistance with the country of origin of the strains (Italy/Argentina); the type of meat (pork/llama); and the bacterial group (LAB/CNS). The odds ratio $(95 \%$ confidence interval) and the Wald ratio for the associated coefficients were calculated and a Chi-square test was performed to determine the differences between the odds of antibiotic resistance. Statistical analysis and data representation were performed using the XLSTAT software (Addinsoft Corporation, Paris, France, https: / / www.xlstat.com (accessed on 9 July 2021)) and INFOSTAT software (v. 2015).

\section{Results and Discussion}

\subsection{Incidence of Tetracycline and Erythromycin Resistance}

The extensive use of antibiotics as growth promoters in animal husbandry for several decades until it was banned, in addition to the continued abusive misuse of tetracycline and erythromycin to cure or prevent the onset of bacterial infections, have played a pivotal role in the spread of silent reservoirs of antibiotic resistance among food-associated bacteria with their consequent risk to human health [28,29]. 
In this study, phenotypic and genotypic evaluations of tetracycline and erythromycin resistance were performed in LAB and CNS species. Despite the distant origins as well as the different production technologies and kinds of meat (llama vs. pork) used as raw material, L. sakei, L. plantarum, S. saprophyticus, S. xylosus and S. equorum were the dominant species in both the Italian and Argentinean sausages. Table 2 summarizes the phenotypic and genotypic data obtained for the 205 strains analyzed herein.

Table 2. Latilactobacillus (L.) sakei, Lactiplantibacillus (L.) plantarum and Staphylococcus (S.) strains included in this study. Incidence, phenotypic AR and molecular identification of antibiotic-resistant genes.

\begin{tabular}{|c|c|c|c|c|c|c|c|c|c|c|c|c|}
\hline \multirow[t]{2}{*}{ Meat Products } & \multirow[t]{2}{*}{ Species } & \multirow[t]{2}{*}{$\begin{array}{c}\mathbf{N}^{\circ} \text { of } \\
\text { Isolated } \\
\text { Strains }\end{array}$} & \multicolumn{2}{|c|}{$\begin{array}{c}\text { Phenotypic } \\
\text { AR }\end{array}$} & \multicolumn{8}{|c|}{ Genotypic AR } \\
\hline & & & TET & ERY & tet $\mathrm{M}$ & tetK & tet $\mathrm{W}$ & tets & tet $\mathrm{L}$ & ermA & erm $\mathrm{B}$ & erm $\mathrm{C}$ \\
\hline \multirow{6}{*}{$\begin{array}{c}\text { Italian pork } \\
\text { sausages }\end{array}$} & L. sakei & 24 & 17 & 7 & 11 & - & - & - & - & 2 & 5 & - \\
\hline & L. plantarum & 12 & 11 & 6 & 5 & - & 4 & 1 & - & - & 3 & 1 \\
\hline & S. $x y l o s u s$ & 22 & 21 & 5 & - & 18 & - & - & 3 & - & 1 & 2 \\
\hline & S. equorum & 19 & 16 & 11 & - & 10 & - & - & 1 & - & 1 & 4 \\
\hline & S. saprophyticus & 11 & 10 & 3 & - & 9 & - & - & - & - & - & 1 \\
\hline & L. sakei & 33 & 4 & 0 & - & - & - & - & - & - & - & - \\
\hline \multirow{3}{*}{$\begin{array}{c}\text { Argentinean } \\
\text { pork sausages }\end{array}$} & L. plantarum & 7 & 0 & 0 & - & - & - & - & - & - & - & - \\
\hline & S. xylosus & 1 & 0 & 1 & - & - & - & - & - & - & - & - \\
\hline & S. equorum & 2 & 1 & 2 & - & 1 & - & - & - & 1 & 1 & \\
\hline \multirow{7}{*}{$\begin{array}{l}\text { Argentinean } \\
\text { llama sausages }\end{array}$} & S. saprophyticus & 10 & 5 & 4 & - & 2 & - & - & - & - & - & - \\
\hline & L. sakei & 40 & 0 & 0 & - & - & - & - & - & - & - & - \\
\hline & L. plantarum & 5 & 0 & 0 & - & - & - & - & - & - & - & - \\
\hline & S. $x y l o s u s$ & 2 & 1 & 0 & 1 & 1 & - & - & - & - & - & - \\
\hline & S. equorum & 10 & 0 & 3 & - & - & - & - & - & - & - & - \\
\hline & S. saprophyticus & 7 & 4 & 2 & - & 4 & - & - & - & - & - & - \\
\hline & & 205 & 90 & 44 & 17 & 45 & 4 & 1 & 4 & 3 & 11 & 7 \\
\hline & \multicolumn{2}{|c|}{ AR incidence $\%$} & 43.9 & 21.5 & 8.293 & 21.95 & 1.951 & 0.488 & 1.95 & 0.488 & 5.366 & 3.415 \\
\hline
\end{tabular}

Overall, phenotypic tetracycline resistance (TET-R) had a higher incidence (43.9\%) than erythromycin resistance (ERY-R) (21,5\%) in the 205 analyzed strains, mainly observed in Italian pork sausages (Table 2). Particularly, among L. sakei and L. plantarum strains, 32 out of $121(26.4 \%)$ were TET-R (only four strains from Argentinean sausages) and 13 strains $(10.7 \%)$ were ERY-R (all of them isolated from Italian salami). Considering the different species, L. plantarum showed higher TET-R and ERY-R incidence (45.8\% and $25 \%$, respectively) than L. sakei $(21.6 \%$ and $7.2 \%$, respectively). These results are in accordance with those reviewed by Fraqueza [1] regarding the AR of LAB isolated from dry fermented sausages.

As far as the 84 CNS strains are concerned, 58 strains were TET-R (69\%) and 31 were ERY-R (36.9\%) with higher incidence in Italian sausages for both phenotypes. S. xylosus was the most TET resistant species (88\%), followed by S. saprophyticus (67.8\%) and S. equorum (54.8\%); on the contrary, $51.6 \%$ of S. equorum was ERY-R followed by S. saprophyticus (32.1\%) and S. xylosus (24\%). Similar AR incidence in CNS strains isolated from meat products and commodities was previously reported [14,16,17,30-33]. Even et al. [31] confirmed that the incidence of TET-R and ERY-R among CNS is species-dependent.

Regarding to the genotype analysis, tet $\mathrm{K}$ was the most widespread gene among the 205 strains, followed by tet M, ermB and ermC (Table 2). Similarly, Garofalo et al. [34] reported that tet $\mathrm{M}$ and tet $\mathrm{K}$ were the prevalent genes for tetracycline resistance, while a high frequency was found for the erm $\mathrm{B}$ and erm $\mathrm{C}$ genes, conferring erythromycin resistance to the pork meat microbiota.

In accordance with Rebecchi et al. [17], the tetK gene was widespread among CNS isolated from Italian pork sausages, while only one $S$. xylosus strain from the llama product harbored the tet $\mathrm{M}$ determinant. This latter gene was prevalent among L. sakei and L. plantarum isolates, while tetS/tetW were only detected in L. plantarum from Italian salami. The 
erm B gene was predominant in LAB, particularly in L. sakei, while erm $\mathrm{C}$ was frequently detected among CNS, mainly in S. equorum.

In this study, selected genes conferring resistance to tetracycline and erythromycin were investigated since they represented some of the most widely distributed among food lactobacilli and CNS $[2,16,17,35]$. In this sense, discrepancies between the phenotype and genotype profiles were observed from our results: $21.1 \%$ of tetracycline and $52.3 \%$ of erythromycin-resistant strains did not harbor the respective genetic determinants investigated in this study (Table 2). Among lactobacilli, more discrepancies were observed regarding to tetracycline phenotype/genotype, while a high number of ERY-R CNS resulted as genetically susceptible. This discordance between the phenotype and genotype was already reported by other authors $[18,31,36]$ and may be explained by the presence of additional genes conferring resistance different than those investigated herein $[20,34,37]$. For example, many genes conferring tetracycline resistance were described, and among these, tet $\mathrm{O}$, tet $\mathrm{Q}$, tet $36, t e t \mathrm{Z}$, tet $\mathrm{O} / \mathrm{W} / 32 / \mathrm{O} / \mathrm{W} / \mathrm{O}$, tet $\mathrm{W} / \mathrm{O}$ genes were also identified among lactobacilli [38]. With regard to erythromycin resistance, especially among CNS, two main resistance mechanism were identified: ribosomal binding site modification mediated by family of erm genes (erm $\mathrm{A}, \operatorname{erm} \mathrm{B}, \operatorname{erm} \mathrm{C}$, erm $\mathrm{Y}$, and $\operatorname{erm} \mathrm{F})$ and macrolide efflux mediated by mef A, msrA/B genes [37,39,40].

In contrast to our findings, a susceptible phenotype but resistant genotype have been also reported [41,42] and could be due to the low levels and down regulation of gene expression or by an inactive gene product (a mechanism known as silent genes) $[36,42]$

\subsection{Correlation between Phenotype and Genotype}

A high correlation (Pearson's correlation coefficient $P C=0.659$ ) between phenotypic TET-R and ERY-R and genotypic features was observed within the LAB group (Figure 1A). The phenotype TET-R in LAB was highly correlated with the tet $\mathrm{M}$ gene $(\mathrm{PC}=0.743)$, and ERY-R was highly correlated with the erm $\mathrm{B}$ gene $(\mathrm{PC}=0.808)$, followed by erm $\mathrm{A}$ and erm $\mathrm{C}$ genes with significant correlation $(\mathrm{PC}=0.505)$ (Figure $1 \mathrm{~A})$. The TET-R and ERY-R associations and the corresponding genetic determinants are the most frequently described in LAB $[6,13,43-46]$. In fact, several studies have reported that TET and ERY resistance genes are highly transferable due to their association with known transposable elements $[35,47,48]$.

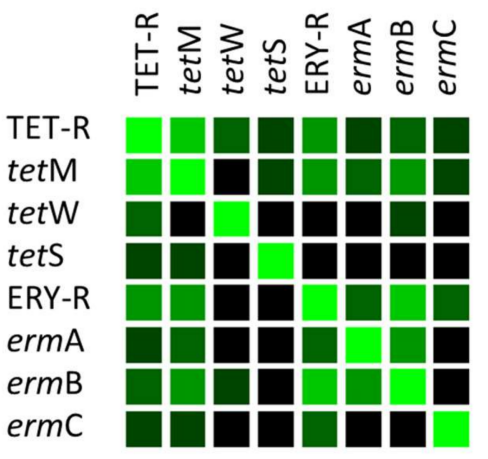

A

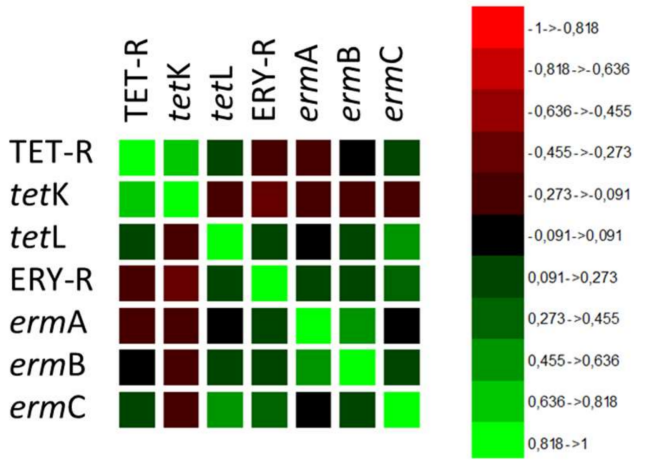

B

Figure 1. Correlation matrix of phenotypic and genotypic features regarding tetracycline and erythromycin antibiotic resistance in (A) LAB species and (B) CNS species.

In the CNS group (Figure 1B), contrarily to pathogenic staphylococci such as S. aureus [49], no correlation between the TET-R and ERY-R phenotypes was observed ( $P C=-0.092)$. TET-R was positively correlated with the occurrence of the tet K gene $(\mathrm{PC}=0.702)$, while ERY-R was correlated with the presence of the erm $\mathrm{C}$ gene $(\mathrm{PC}=0.405)$ followed by the erm $\mathrm{B}$ gene $(\mathrm{PC}=0.258)$. The high prevalence of tet $\mathrm{K}$ related to tetracycline resistance in CNS was reported by other authors [14,31-33]. In addition to tetK and other AR genes such 
as blaZ, tet $\mathrm{M}, \ln u \mathrm{~A}, \operatorname{erm} \mathrm{B}$ and $\operatorname{erm} \mathrm{C}$ may be located on transferable plasmids; therefore antibiotic-resistant $\mathrm{CNS}$ can act as a reservoir and vehicle for human bacteria, representing an important hazard in fermented food [31,50].

\subsection{Correlation between the Tetracycline and Erythromycin MICs Values and Their Genetic Determinants}

The correlation between the MIC values and the genetic determinant incidence was investigated. For the LAB strains, both the MICs and the presence of genes were strictly strain dependent, as shown in Table 3 . The Chi-square test $(\mathrm{df}=15)=46.53, p<0.0001)$ and Pearson's contingency coefficient $(\mathrm{PC}=0.77)$ demonstrated a strong association between the high MICs and the presence of at least one genetic determinant among the TET-R LAB strains.

Table 3. Tetracycline (TET-R) and erythromycin (ERY-R)-resistant LAB species: Latilactobacillus (L.) sakei and Lactiplantibacillus (L.) plantarum. MIC values measured by broth microdilution method using LSM $(\mu \mathrm{g} / \mathrm{mL})$ and the distribution of genetic determinants investigated in this study.

\begin{tabular}{|c|c|c|c|c|c|c|c|c|c|c|c|}
\hline \multirow[t]{2}{*}{ LAB } & & \multirow{2}{*}{$\begin{array}{c}\text { TET-R } \\
\text { MIC }\end{array}$} & \multicolumn{5}{|c|}{ Genetic Determinant } & \multirow{2}{*}{$\begin{array}{c}\text { ERY-R } \\
\text { MIC }\end{array}$} & \multicolumn{3}{|c|}{ Genetic Determinant } \\
\hline & & & tet $\mathrm{M}$ & tet $\mathrm{K}$ & tet $\mathrm{W}$ & tet $\mathrm{S}$ & tet $\mathrm{L}$ & & ermA & erm $\mathrm{B}$ & erm $\mathrm{C}$ \\
\hline \multirow[t]{21}{*}{ L. sakei } & UC103 & 64 & & & & & & & & & \\
\hline & UC109 & 32 & & & & & & 4 & & & \\
\hline & UC12 & 16 & & & & & & & & & \\
\hline & UC128 & 128 & & & & & & 4 & & & \\
\hline & UC13 & 128 & & & & & & 128 & & & \\
\hline & UC131 & 256 & & & & & & 256 & & & \\
\hline & UC133 & 64 & & & & & & & & & \\
\hline & UC136 & 64 & & & & & & & & & \\
\hline & UC17 & 16 & & & & & & & & & \\
\hline & UC23 & 16 & & & & & & 32 & & & \\
\hline & UC32 & 32 & & & & & & & & & \\
\hline & UC35 & 16 & & & & & & & & & \\
\hline & UC38 & 16 & & & & & & & & & \\
\hline & UC49 & 64 & & & & & & 32 & & & \\
\hline & UC57 & 64 & & & & & & & & & \\
\hline & UC65 & 64 & & & & & & & & & \\
\hline & UC89 & 256 & & & & & & 128 & & & \\
\hline & UC9096 & 16 & & & & & & & & & \\
\hline & UC9097 & 16 & & & & & & & & & \\
\hline & UC8437 & 16 & & & & & & & & & \\
\hline & UC8438 & 16 & & & & & & & & & \\
\hline \multirow[t]{11}{*}{ L. plantarum } & UC108 & 256 & & & & & & & & & \\
\hline & UC125 & 256 & & & & & & 512 & & & \\
\hline & UC126 & 256 & & & & & & 256 & & & \\
\hline & UC129 & 256 & & & & & & 128 & & & \\
\hline & UC144 & 64 & & & & & & & & & \\
\hline & UC145 & 64 & & & & & & & & & \\
\hline & UC146 & 256 & & & & & & 256 & & & \\
\hline & UC2 & 512 & & & & & & & & & \\
\hline & UC24 & 512 & & & & & & & & & \\
\hline & UC25 & 128 & & & & & & 4 & & & \\
\hline & UC7 & 64 & & & & & & 4 & & & \\
\hline
\end{tabular}

In accordance with the data reported by other authors [6,13,51], we observed that the presence of the tet $\mathrm{M}$ gene was associated with different MIC values (32-256 $\mu \mathrm{g} / \mathrm{mL}$ ) among the lactobacilli strains evaluated. Comunian et al. [13] reported that increasing tet $\mathrm{M}$ transcript levels were correlated with increasing MIC values, suggesting that the expression of this gene is tetracycline concentration dependent. Furthermore, Ammor et al. [52] ob- 
served that the presence of more than one tetracycline resistance gene resulted in elevated MICs. In this study, the highest MIC value $(512 \mu \mathrm{g} / \mathrm{mL})$ was observed in two L. plantarum strains, one harboring tet $\mathrm{M}$ and tetS and one carrying only tetW (Table 3).

Additionally, for the phenotype ERY-R in lactobacilli, there was an association between high MICs $(>16 \mu \mathrm{g} / \mathrm{mL})$ and the occurrence of at least one genetic determinant $(p<0.0630$; Pearson's contingency coefficient $=0.78)$. Strains with lower MICs $(4$ and $16 \mu \mathrm{g} / \mathrm{mL})$ were negative for the genetic determinants investigated herein. As stated above and detailed in Table 3, all lactobacilli strains that were ERY-R were also TET-R. For the ERY-R strains, only the presence of ermB resulted in elevated MICs $(32-512 \mu \mathrm{g} / \mathrm{mL})$ among lactobacilli strains. The simultaneous occurrence of erm $\mathrm{A}$ and erm $\mathrm{B}$ was observed in only two L. sakei strains with MICs of 32 and $128 \mu \mathrm{g} / \mathrm{mL}$, respectively, while ermC was detected in only one L. plantarum strain with an MIC of $128 \mu \mathrm{g} / \mathrm{mL}$ (Table 3).

In the CNS group (Table 4), resistance to both tetracycline and to erythromycin was observed with MICs $\geq 32 \mu \mathrm{g} / \mathrm{mL}$. Unlike lactobacilli, no association was observed between higher MICs and the presence of the genetic determinants here investigated herein (Chi-square of Pearson $(\mathrm{df}=12)=8.94, p=0.7084$; Pearson's contingency coefficient $=0.37$ and Chi-square of Pearson $(\mathrm{df}=12)=10.87, p=0.5399$; and Pearson's contingency coefficient $=0.52$, respectively). In fact, nine strains displaying higher tetracycline MIC $(\geq 128 \mu \mathrm{g} / \mathrm{mL})$ and 16 strains with erythromycin MIC $\geq 64 \mu \mathrm{g} / \mathrm{mL}$ were negative for all the genes analyzed in this study (Table 4 ). Among the TET-R CNS carrying the tetK gene, $77.6 \%$ showed MICs ranging from $32 \mu \mathrm{g} / \mathrm{mL}$ to $512 \mu \mathrm{g} / \mathrm{mL}$; the co-occurrence of tet $\mathrm{K}$ and tet $\mathrm{L}$ was only observed in two S. xylosus strains displaying an MIC of $128 \mu \mathrm{g} / \mathrm{mL}$. The presence of only tet $\mathrm{L}$ was detected in two strains displaying a high tetracycline MIC $(256 \mu \mathrm{g} / \mathrm{mL})$. Our results indicated that the presence of more than one genetic determinant for tetracycline did not determine higher MICs. The same behavior was observed for one $S$. equorum strain with erythromycin resistance, carrying erm $\mathrm{A}$ and $\operatorname{ermB}$ (MIC of $32 \mu \mathrm{g} / \mathrm{mL}$ ). The seven CNS strains harboring the erm $\mathrm{C}$ gene were associated with high erythromycin MIC values $(256 \mu \mathrm{g} / \mathrm{mL})$. Even if CNS may represent a potential safety hazard because some strains are multi-resistant to antibiotics, others display a complete lack of $\mathrm{AR}$, indicating that the AR is strictly strain dependent $[31,33,50,53]$.

Table 4. Tetracycline- (TET-R) and erythromycin- (ERY-R) resistant Staphylococcus strains. MIC values were measured by broth microdilution method using CAMHB $(\mu \mathrm{g} / \mathrm{mL})$ and the distribution of the genetic determinants investigated in this study.

\begin{tabular}{|c|c|c|c|c|c|c|c|c|c|c|c|}
\hline \multirow[t]{2}{*}{$\begin{array}{c}\text { Staphylococcus } \\
\text { (S) }\end{array}$} & & \multirow{2}{*}{$\begin{array}{l}\text { TET-R } \\
{ }^{*} \mathrm{MIC}\end{array}$} & \multicolumn{5}{|c|}{ Genetic Determinants } & \multirow{2}{*}{$\begin{array}{c}\text { ERY-R } \\
{ }^{*} \mathrm{MIC}\end{array}$} & \multicolumn{3}{|c|}{$\begin{array}{c}\text { Genetic } \\
\text { Determinants }\end{array}$} \\
\hline & & & tet $\mathrm{M}$ & tet $\mathrm{K}$ & tet $\mathrm{W}$ & tets & tet $\mathrm{L}$ & & ermA & ermB & erm $\mathrm{C}$ \\
\hline \multirow[t]{22}{*}{ S. saprophyticus } & UC8721 & & & & & & & 32 & & & \\
\hline & UC8722 & & & & & & & 64 & & & \\
\hline & UC8723 & 32 & & & & & & & & & \\
\hline & UC8724 & 32 & & & & & & & & & \\
\hline & UC8738 & 32 & & & & & & & & & \\
\hline & UC8731 & 32 & & & & & & 64 & & & \\
\hline & UC8736 & 32 & & & & & & & & & \\
\hline & UC7548 & & & & & & & 64 & & & \\
\hline & UC7557 & 64 & & & & & & & & & \\
\hline & UC7547 & 64 & & & & & & & & & \\
\hline & UC7546 & 64 & & & & & & & & & \\
\hline & UC7545 & 64 & & & & & & & & & \\
\hline & UC117 & 256 & & & & & & & & & \\
\hline & UC905 & 128 & & & & & & 256 & & & \\
\hline & UC929 & 256 & & & & & & 128 & & & \\
\hline & UC705 & 128 & & & & & & & & & \\
\hline & UC51 & 128 & & & & & & & & & \\
\hline & UC732 & 128 & & & & & & & & & \\
\hline & UC879 & 256 & & & & & & 256 & & & \\
\hline & UC797 & 256 & & & & & & & & & \\
\hline & UC114 & 128 & & & & & & & & & \\
\hline & UC111 & 256 & & & & & & & & & \\
\hline
\end{tabular}


Table 4. Cont.

\begin{tabular}{|c|c|c|c|c|c|c|c|c|c|c|c|}
\hline \multirow[t]{2}{*}{$\begin{array}{c}\text { Staphylococcus } \\
\text { (S) }\end{array}$} & & \multicolumn{2}{|l|}{ TET-R } & \multicolumn{4}{|c|}{ Genetic Determinants } & \multirow{2}{*}{$\begin{array}{l}\text { ERY-R } \\
{ }^{*} \mathrm{MIC}\end{array}$} & \multicolumn{3}{|c|}{$\begin{array}{c}\text { Genetic } \\
\text { Determinants }\end{array}$} \\
\hline & & ${ }^{*} \mathrm{MIC}$ & tet $\mathrm{M}$ & tetK & tet $\mathrm{W}$ & tets & tet $\mathrm{L}$ & & ermA & ermB & ermC \\
\hline \multirow[t]{23}{*}{ S. xylosus } & UC7543 & 64 & & & & & & & & & \\
\hline & UC8727 & & & & & & & 32 & & & \\
\hline & UC662 & 256 & & & & & & & & & \\
\hline & UC666 & 128 & & & & & & & & & \\
\hline & UC741 & 512 & & & & & & & & & \\
\hline & UC761 & 256 & & & & & & & & & \\
\hline & UC852 & 256 & & & & & & & & & \\
\hline & UC862 & 256 & & & & & & 256 & & & \\
\hline & UC132 & 256 & & & & & & 256 & & & \\
\hline & UC756 & 512 & & & & & & & & & \\
\hline & UC776 & 512 & & & & & & 128 & & & \\
\hline & UC109 & 128 & & & & & & & & & \\
\hline & UC101 & 128 & & & & & & & & & \\
\hline & UC789 & 256 & & & & & & & & & \\
\hline & UC897 & 256 & & & & & & 256 & & & \\
\hline & UC120 & 128 & & & & & & & & & \\
\hline & UC48 & 128 & & & & & & & & & \\
\hline & UC113 & 128 & & & & & & & & & \\
\hline & UC119 & 128 & & & & & & & & & \\
\hline & UC115 & 128 & & & & & & & & & \\
\hline & UC431 & 128 & & & & & & & & & \\
\hline & UC432 & 128 & & & & & & 256 & & & \\
\hline & UC784 & 512 & & & & & & & & & \\
\hline \multirow[t]{24}{*}{ S. equorum } & UC8728 & & & & & & & 32 & & & \\
\hline & UC8729 & 32 & & & & & & & & & \\
\hline & UC7559 & & & & & & & 64 & & & \\
\hline & UC7568 & & & & & & & 32 & & & \\
\hline & UC7569 & & & & & & & 64 & & & \\
\hline & UC773 & 256 & & & & & & & & & \\
\hline & UC133 & 5 & & & & & & 128 & & & \\
\hline & UC79 & 128 & & & & & & 256 & & & \\
\hline & UC917 & 512 & & & & & & 256 & & & \\
\hline & UC740 & 256 & & & & & & 256 & & & \\
\hline & UC753 & 256 & & & & & & 256 & & & \\
\hline & UC638 & 128 & & & & & & 256 & & & \\
\hline & UC105 & 256 & & & & & & & & & \\
\hline & UC123 & 256 & & & & & & & & & \\
\hline & UC786 & 256 & & & & & & 128 & & & \\
\hline & UC829 & 256 & & & & & & & & & \\
\hline & UC823 & & & & & & & 128 & & & \\
\hline & UC934 & & & & & & & 256 & & & \\
\hline & UC629 & & & & & & & 256 & & & \\
\hline & UC127 & 128 & & & & & & 256 & & & \\
\hline & UC121 & 256 & & & & & & & & & \\
\hline & UC122 & 256 & & & & & & & & & \\
\hline & UC832 & 256 & & & & & & & & & \\
\hline & UC102 & 256 & & & & & & & & & \\
\hline
\end{tabular}

Positive for the antibiotic resistance genetic determinant $\square *$ MICs for TET and ERY $(\mu \mathrm{g} / \mathrm{mL})$ 256-512.

3.4. LAB and CNS AR Phenotypes: Association with Country of Origin and Manufacturing Practices

Considering the diverse breeding and manufacturing conditions in Italy and Argentina (intensive vs. extensive practices and the meat production environment, etc.), a multiple correspondence analysis (MCA) was performed to determine the relationships between the country of origin and the TET-R and ERY-R phenotype. The first analysis in Figure 2 
clearly distinguished the AR phenotypes (TET-R and ERY-R) associated with the genus Staphylococcus belonging to Italian salami from those susceptible of being directly associated with LAB from the Argentinean sausages (TET-S and ERY-S).

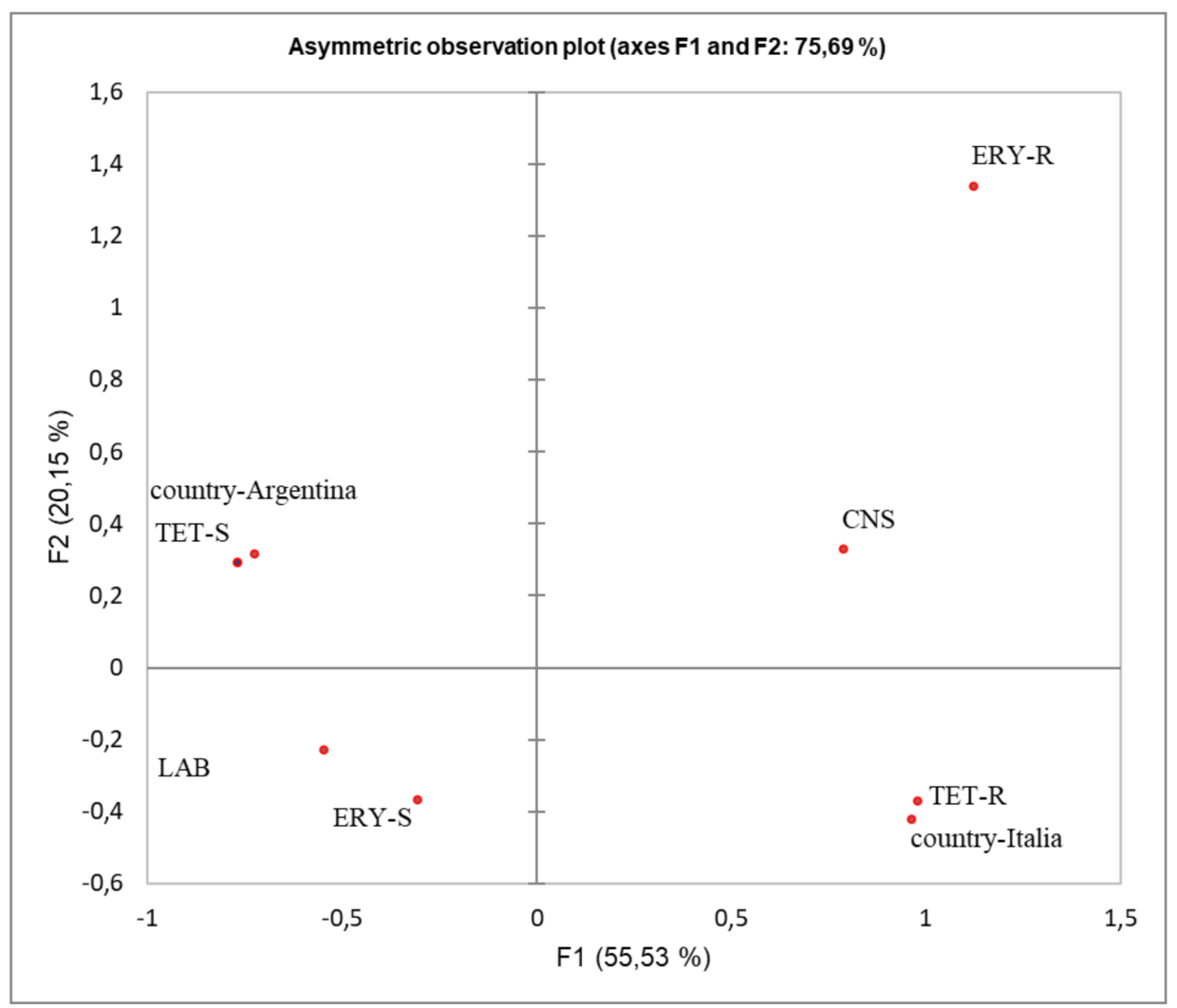

Figure 2. Multivariate correspondence analysis (MCA) summarizing the associations between antibiotic resistance phenotypes ( $\mathrm{R}$ and $\mathrm{S}$ ) regarding the LAB and CNS groups isolated from Italian and Argentinean fermented sausages. The contribution to the Chi-squared test is indicated for each axis.

In fact, all LAB strains isolated from Argentinean sausages were susceptible to ERY and only four L. sakei strains (10\%) were TET-R.

Additionally, when the different type of meat used and the bacterial species were considered (Figure 3), both AR phenotypes were associated with pork meat, mainly of Italian origin (Figure 2), where intensive practices were used. Moreover, the analysis showed that the TET-R phenotype was associated with S. xylosus and to a lesser extent, with S. saprophyticus, while ERY-R was associated with L. plantarum and S. equorum. On the contrary, the TET-S and ERY-S phenotypes were correlated with $L$. sakei from llama meat.

From the MCA, considering either the geographical location or type of meat used, we observed that the AR phenotype of the analyzed strains was associated with Italy and pork meat. Since the Italian fermented products considered in this study were produced using pork meat from intensive farming, we could assume that the strong association observed would be related to farm practices.

To date, very few studies have investigated the frequency of phenotypic antibiotic resistance in the native microbiota of fermented meat products in relation to manufacturing practices.

The emergence and spread of antibiotic resistance associated with the use of antibiotics in livestock are very complex phenomena with multifaceted effects not only associated with a limited or specific geographical area but which rather depend on farming management $[54,55]$. The worldwide antibiotics' misuse in the animal farm, particularly in intensive breeding, has promoted a spread of foodborne AR bacteria. Even though there 
has been an attempt to control the abusive misuse of antibiotics worldwide (since 2006, the European Union has officially banned the use of antibiotics as feed additives), human "intensive activities", along with their negative environmental impacts, have contributed to expanding the environmental reservoirs of AR genes [56].

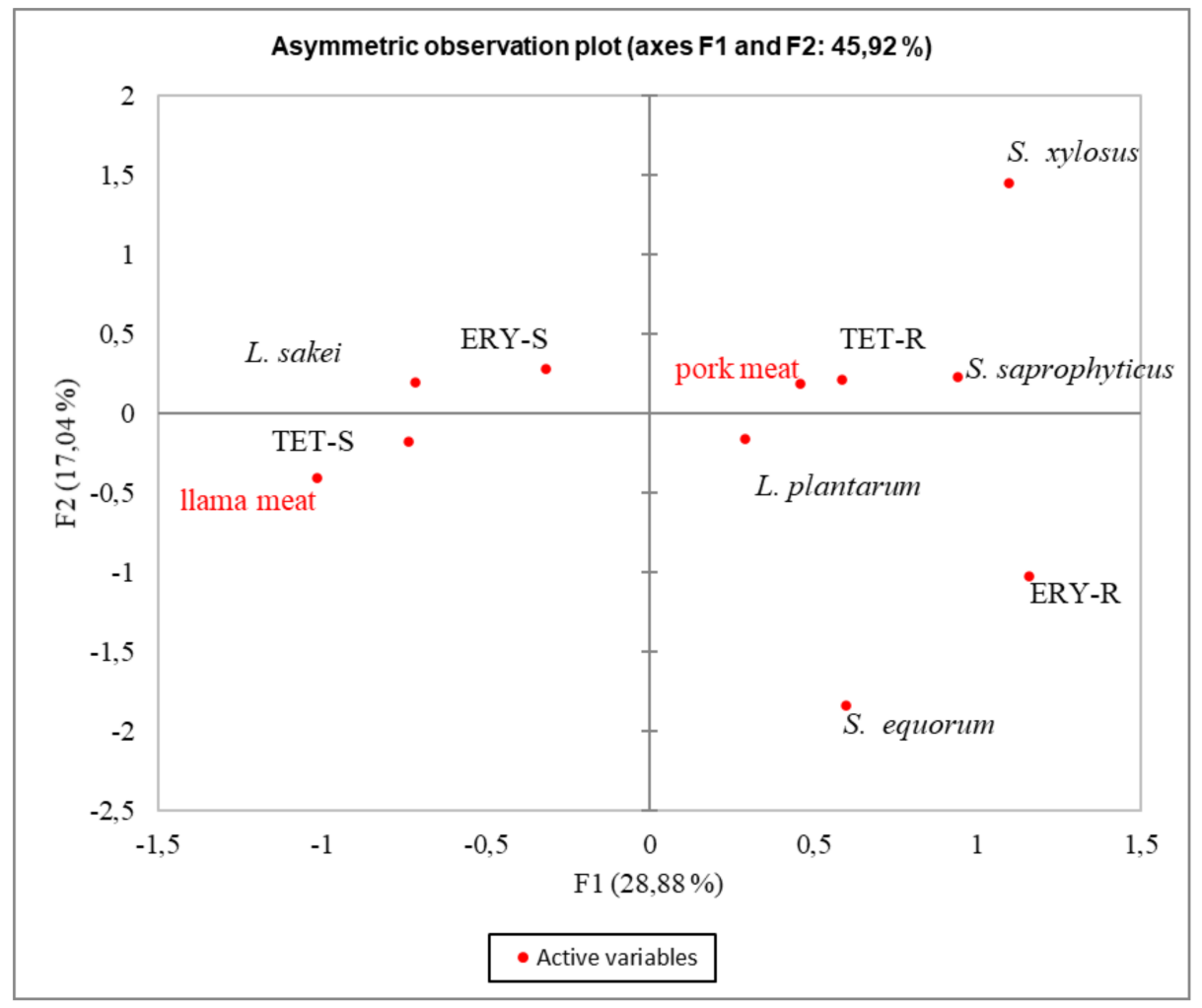

Figure 3. Multivariate correspondence analysis (MCA) summarizing the associations between antibiotic resistance phenotypes ( $\mathrm{R}$ and $\mathrm{S}$ ) among Latilactobacillus (L.) sakei, Lactiplantibacillus (L.) plantarum, and Staphylococcus (S) species isolated from pork meat and llama meat fermented products. The contribution to the Chi-squared test is indicated for each axis.

The results obtained in our study demonstrated that the farming practices and the food production context (extensive areas, small food facilities with less negative environmental impact) could influence the different AR occurrence in meat-associated bacteria rather than the different geographical areas considered (Argentina and Italy). Similarly, Haskell et al. [57] reported that the lower rates of antibiotic resistance for Staphylococcus aureus found in antibiotic-free animals could apply to other bacterial species. Additionally, antibiotic resistance levels in Enterococcus species significantly decreased in a poultry farm in the USA which transitioned from common antibiotic use to organic practices [58]. In addition, Comunian et al. [13] detected the highest number of Lacticaseibacillus paracasei resistant strains in fermented meat foods produced in Italian geographical regions where more intensive practices are applied in animal farming.

\section{Conclusions}

In the current study, 205 strains belonging to the LAB and CNS groups isolated from Argentinean and Italian sausages were phenotypically characterized for their resistance to tetracycline and erythromycin, as well as for the presence of their genetic determinants. A higher incidence of TET-R compared to ERY-R was found among the analyzed strains. All lactobacilli strains which were ERY-R were also TET-R, showing a strong association between the high MIC values and the presence of at least one genetic determinant. Regarding the resistant CNS strains, despite the high MIC values observed, no association with the presence of the genetic determinant investigated was found. 
Data analysis highlighted the association between the AR phenotypes and Staphylococcus species isolated from Italian salami, while the susceptible phenotypes (TET-S and ERY-S) were associated with the lactobacilli from pork and llama Argentinean sausages. Our findings suggest that TET-R and ERY-R are probably related to certain animal breeding and manufacturing practices rather than the type of meat.

Since animal production systems are not closed ecosystems, antibiotic resistance in meat-associated bacteria is a very complex phenomenon possessing multifaceted effects which is not only associated with a limited specific geographical area but is also significantly affected by different human activities in the environment. The assessment of bacterial resistance in different environmental contexts will help in monitoring the impact of different farming practices and the food production chain on the incidence and spread of antibiotic resistance.

Supplementary Materials: The following are available online at https://www.mdpi.com/article/10 $.3390 /$ microorganisms9102111/s1, Table S1. Primer used in this study.

Author Contributions: Conceptualization, C.F., A.R., L.M. and V.P.; Methodology, C.F., A.R. and C.M.L.; Formal analysis, C.F. and A.R.; Investigation, C.M.L. and A.R.; Data curation, C.F., A.R. and L.M.; Writing—original draft preparation, C.F., A.R. and V.P.; Writing—review and editing, C.F. and A.R.; Supervision, L.M. All authors have read and agreed to the published version of the manuscript.

Funding: This research received no external funding.

Institutional Review Board Statement: Not applicable.

Informed Consent Statement: Not applicable.

Data Availability Statement: Not applicable.

Conflicts of Interest: The authors declare no conflict of interest.

\section{References}

1. Fraqueza, M.J. Antibiotic resistance of lactic acid bacteria isolated from dry-fermented sausages. Int. J. Food Microbiol. 2015, 212, 76-88. [CrossRef] [PubMed]

2. Anisimova, E.; Yarullina, D. Characterization of Erythromycin and Tetracycline Resistance in Lactobacillus fermentum Strains. Int. J. Microbiol. 2018, 2018, 3912326. [CrossRef] [PubMed]

3. Heo, S.; Lee, J.-H.; Jeong, D.-W. Food-derived coagulase-negative Staphylococcus as starter cultures for fermented foods. Food Sci. Biotechnol. 2020, 29, 1023-1035. [CrossRef]

4. Tang, K.L.; Caffrey, N.P.; Nóbrega, D.; Cork, S.C.; Ronksley, P.E.; Barkema, H.; Polachek, A.J.; Ganshorn, H.; Sharma, N.; Kellner, J.; et al. Restricting the use of antibiotics in food-producing animals and its associations with antibiotic resistance in food-producing animals and human beings: A systematic review and meta-analysis. Lancet Planet. Health 2017, 1, e316-e327. [CrossRef]

5. Bacanll, M.; Başaran, N. Importance of antibiotic residues in animal food. Food Chem. Toxicol. 2019, 125, 462-466. [CrossRef]

6. Gevers, D.; Danielsen, M.; Huys, G.; Swings, J. Molecular Characterization of tet (M) Genes in Lactobacillus Isolates from Different Types of Fermented Dry Sausage. Appl. Environ. Microbiol. 2003, 69, 1270-1275. [CrossRef]

7. Gevers, D.; Huys, G.; Devlieghere, F.; Uyttendaele, M.; Debevere, J.; Swings, J. Isolation and Identification of Tetracycline Resistant Lactic Acid Bacteria from Pre-packed Sliced Meat Products. Syst. Appl. Microbiol. 2000, 23, 279-284. [CrossRef]

8. Aymerich, T.; Martin, B.; Garriga, M.; Vidal-Carou, M.C.; Bover-Cid, S.; Hugas, M. Safety properties and molecular strain typing of lactic acid bacteria from slightly fermented sausages. J. Appl. Microbiol. 2005, 100, 40-49. [CrossRef]

9. Landeta, G.; Curiel, J.; Carrascosa, A.; Muñoz, R.; Rivas, B.D.L. Characterization of coagulase-negative staphylococci isolated from Spanish dry cured meat products. Meat Sci. 2013, 93, 387-396. [CrossRef]

10. Federici, S.; Ciarrocchi, F.; Campana, R.; Ciandrini, E.; Blasi, G.; Baffone, W. Identification and functional traits of lactic acid bacteria isolated from Ciauscolo salami produced in Central Italy. Meat Sci. 2014, 98, 575-584. [CrossRef] [PubMed]

11. Zonenschain, D.; Rebecchi, A.; Morelli, L. Erythromycin- and tetracycline-resistant lactobacilli in Italian fermented dry sausages. J. Appl. Microbiol. 2009, 107, 1559-1568. [CrossRef]

12. Fontana, C.; Bassi, D.; López, C.; Pisacane, V.; Otero, M.C.; Puglisi, E.; Rebecchi, A.; Cocconcelli, P.S.; Vignolo, G. Microbial ecology involved in the ripening of naturally fermented llama meat sausages. A focus on lactobacilli diversity. Int. J. Food Microbiol. 2016, 236, 17-25. [CrossRef] [PubMed]

13. Comunian, R.; Daga, E.; Duprè, I.; Paba, A.; Devirgiliis, C.; Piccioni, V.; Perozzi, G.; Zonenschain, D.; Rebecchi, A.; Morelli, L.; et al. Susceptibility to tetracycline and erythromycin of Lactobacillus paracasei strains isolated from traditional Italian fermented foods. Int. J. Food Microbiol. 2010, 138, 151-156. [CrossRef] [PubMed] 
14. Marty, E.; Bodenmann, C.; Buchs, J.; Hadorn, R.; Eugster-Meier, E.; Lacroix, C.; Meile, L. Prevalence of antibiotic resistance in coagulase-negative staphylococci from spontaneously fermented meat products and safety assessment for new starters. Int. J. Food Microbiol. 2012, 159, 74-83. [CrossRef] [PubMed]

15. Nunes, R.S.C.; Del Aguila, E.M.; Paschoalin, V. Safety Evaluation of the Coagulase-Negative Staphylococci Microbiota of Salami: Superantigenic Toxin Production and Antimicrobial Resistance. BioMed Res. Int. 2015, 2015, 483548. [CrossRef]

16. Simeoni, D.; Rizzotti, L.; Cocconcelli, P.; Gazzola, S.; Dellaglio, F.; Torriani, S. Antibiotic resistance genes and identification of staphylococci collected from the production chain of swine meat commodities. Food Microbiol. 2008, 25, 196-201. [CrossRef]

17. Rebecchi, A.; Pisacane, V.; Callegari, M.; Puglisi, E.; Morelli, L. Ecology of antibiotic resistant coagulase-negative staphylococci isolated from the production chain of a typical Italian salami. Food Control. 2015, 53, 14-22. [CrossRef]

18. Rebecchi, A.; Miragoli, F.; Lopez, C.; Bassi, D.; Fontana, C. Exploring Coagulase-Negative Staphylococci Diversity from Artisanal Llama Sausages: Assessment of Technological and Safety Traits. Microorganisms 2020, 8, 629. [CrossRef]

19. Animal Production, Antimicrobial Resistance, Food and Agriculture Organization of the United Nations. Available online: http:/ / www.fao.org/antimicrobial-resistance/key-sectors/animal-production/en/ (accessed on 9 July 2021).

20. Leroy, F.; Geyzen, A.; Janssens, M.; De Vuyst, L.; Scholliers, P. Meat fermentation at the crossroads of innovation and tradition: A historical outlook. Trends Food Sci. Technol. 2013, 31, 130-137. [CrossRef]

21. Van Reckem, E.; Geeraerts, W.; Charmpi, C.; Van Der Veken, D.; De Vuyst, L.; Leroy, F. Exploring the Link Between the Geographical Origin of European Fermented Foods and the Diversity of Their Bacterial Communities: The Case of Fermented Meats. Front. Microbiol. 2019, 10, 2302. [CrossRef]

22. Rebecchi, A.; Callegari, M.L.; Pisacane, V. Integrated Assessment of Antibiotic Resistant Staphylococci in Italian Fermented Sausage. In Proceedings of the 2nd International Symposium on Fermented Meat, Valencia, Spain, 20-23 October 2014; Toldrà, F., Flores, M., Eds.; [CrossRef]

23. Fontana, C.; Cocconcelli, P.S.; Vignolo, G. Monitoring the bacterial population dynamics during fermentation of artisanal Argentinean sausages. Int. J. Food Microbiol. 2005, 103, 131-142. [CrossRef]

24. ISO-ISO 10932:2010. Milk and Milk Products-Determination of the Minimal Inhibitory Concentration (MIC) of Antibiotics Applicable to Bifidobacteria and Non-Enterococcal Lactic Acid Bacteria (LAB). Available online: https://www.iso.org/standard/ 46434.html (accessed on 19 December 2020).

25. Clinical and Laboratory Standards Institute. Performance Standards for Antimicrobial Susceptibility Testing; Twenty-Second Informational Supplement; Clinical and Laboratory Standards Institute: Annapolis Junction, MD, USA, 2012; Volume 32, ISBN 1562387855.

26. Klare, I.; Konstabel, C.; Werner, G.; Huys, G.; Vankerckhoven, V.; Kahlmeter, G.; Hildebrandt, B.; Müller-Bertling, S.; Witte, W.; Goossens, H. Antimicrobial susceptibilities of Lactobacillus, Pediococcus and Lactococcus human isolates and cultures intended for probiotic or nutritional use. J. Antimicrob. Chemother. 2007, 59, 900-912. [CrossRef] [PubMed]

27. EFSA Panel on Additives and Products or Substances used in Animal Feed (FEEDAP). Guidance on the assessment of bacterial susceptibility to antimicrobials of human and veterinary importance. EFSA J. 2012, 10, 2740. [CrossRef]

28. Founou, L.L.; Founou, R.C.; Essack, S. Antibiotic Resistance in the Food Chain: A Developing Country-Perspective. Front. Microbiol. 2016, 7, 1881. [CrossRef] [PubMed]

29. World Health Organization. Antimicrobial Resistance: Global Report on Surveillance. 2014. Available online: https://apps.who. int/iris/handle/10665/112642 (accessed on 9 July 2021).

30. Martin, B.; Garriga, M.; Hugas, M.; Bover-Cid, S.; Veciana-Nogués, M.T.; Aymerich, T. Molecular, technological and safety characterization of Gram-positive catalase-positive cocci from slightly fermented sausages. Int. J. Food Microbiol. 2006, 107, 148-158. [CrossRef]

31. Even, S.; Leroy, S.; Charlier, C.; BEN Zakour, N.; Chacornac, J.-P.; Lebert, I.; Jamet, E.; Desmonts, M.-H.; Coton, E.; Pochet, S. Low occurrence of safety hazards in coagulase negative staphylococci isolated from fermented foodstuffs. Int. J. Food Microbiol. 2010, 139, 87-95. [CrossRef]

32. Kastner, S.; Perreten, V.; Bleuler, H.; Hugenschmidt, G.; Lacroix, C.; Meile, L. Antibiotic susceptibility patterns and resistance genes of starter cultures and probiotic bacteria used in food. Syst. Appl. Microbiol. 2006, 29, 145-155. [CrossRef]

33. Resch, M.; Nagel, V.; Hertel, C. Antibiotic resistance of coagulase-negative staphylococci associated with food and used in starter cultures. Int. J. Food Microbiol. 2008, 127, 99-104. [CrossRef]

34. Garofalo, C.; Vignaroli, C.; Zandri, G.; Aquilanti, L.; Bordoni, D.; Osimani, A.; Clementi, F.; Biavasco, F. Direct detection of antibiotic resistance genes in specimens of chicken and pork meat. Int. J. Food Microbiol. 2007, 113, 75-83. [CrossRef] [PubMed]

35. Ammor, M.S.; Flórez, A.B.; Van Hoek, A.H.; Reyes-Gavilan, C.D.L.; Aarts, H.J.; Margolles, A.; Mayo, B. Molecular Characterization of Intrinsic and Acquired Antibiotic Resistance in Lactic Acid Bacteria and Bifidobacteria. J. Mol. Microbiol. Biotechnol. 2007, 14, 6-15. [CrossRef]

36. Chajęcka-Wierzchowska, W.; Zadernowska, A.; Nalepa, B.; Sierpińska, M.; Łaniewska-Trokenheim, Ł. Coagulase-negative staphylococci (CoNS) isolated from ready-to-eat food of animal origin-Phenotypic and genotypic antibiotic resistance. Food Microbiol. 2015, 46, 222-226. [CrossRef] [PubMed]

37. Schlegelová, J.; Vlkova, H.; Babak, V.; Holasová, M.; Jaglic, Z.; Štosová, T.; Sauer, P. Resistance to erythromycin of Staphylococcus spp. isolates from the food chain. Vet. Med. 2008, 53, 307-314. [CrossRef]

38. Anisimova, E.A.; Yarullina, D.R. Antibiotic Resistance of LACTOBACILLUS Strains. Curr. Microbiol. 2019, 76, 1407-1416. [CrossRef] 
39. Mišić, M.; Čukić, J.; Vidanovic, D.; Šekler, M.; Matić, S.; Vukašinović, M.; Baskić, D. Prevalence of Genotypes That Determine Resistance of Staphylococci to Macrolides and Lincosamides in Serbia. Front. Public Health 2017, 5, 200. [CrossRef]

40. Fijałkowski, K.; Peitler, D.; Karakulska, J. Staphylococci isolated from ready-to-eat meat-Identification, antibiotic resistance and toxin gene profile. Int. J. Food Microbiol. 2016, 238, 113-120. [CrossRef] [PubMed]

41. Chajecka-Wierzchowska, W.; Zadernowska, A.; Nalepa, B.; Sierpinska, M.; Łaniewska-Trokenheim, Ł. Retail Ready-to-Eat Food as a Potential Vehicle for Staphylococcus spp. Harboring Antibiotic Resistance Genes. J. Food Prot. 2014, 77, 993-998. [CrossRef]

42. Morandi, S.; Silvetti, T.; Lopez, J.M.; Brasca, M. Antimicrobial Activity, Antibiotic Resistance and the Safety of Lactic Acid Bacteria in Raw Milk Valtellina Casera Cheese. J. Food Saf. 2014, 35, 193-205. [CrossRef]

43. Danielsen, M. Characterization of the tetracycline resistance plasmid pMD5057 from Lactobacillus plantarum 5057 reveals a composite structure. Plasmid 2002, 48, 98-103. [CrossRef]

44. Devirgiliis, C.; Barile, S.; Perozzi, G. Antibiotic resistance determinants in the interplay between food and gut microbiota. Genes Nutr. 2011, 6, 275-284. [CrossRef]

45. Roberts, M.C. Update on acquired tetracycline resistance genes. FEMS Microbiol. Lett. 2005, 245, 195-203. [CrossRef]

46. Thaker, M.; Spanogiannopoulos, P.; Wright, G.D. The tetracycline resistome. Cell. Mol. Life Sci. 2010, 67, 419-431. [CrossRef]

47. Clewell, D.; Flannagan, S.; Jaworski, D. Unconstrained bacterial promiscuity: The Tn916-Tn1545 family of conjugative transposons. Trends Microbiol. 1995, 3, 229-236. [CrossRef]

48. Mathur, S.; Singh, R. Antibiotic resistance in food lactic acid bacteria-A review. Int. J. Food Microbiol. 2005, 105, 281-295. [CrossRef]

49. Ardic, N.; Ozyurt, M.; Sareyyupoglu, B.; Haznedaroglu, T. Investigation of erythromycin and tetracycline resistance genes in methicillin-resistant staphylococci. Int. J. Antimicrob. Agents 2005, 26, 213-218. [CrossRef] [PubMed]

50. Talon, R.; Leroy, S. Diversity and safety hazards of bacteria involved in meat fermentations. Meat Sci. 2011, 89, 303-309. [CrossRef] [PubMed]

51. Flórez, A.B.; Ammor, M.S.; Mayo, B. Identification of tet(M) in two Lactococcus lactis strains isolated from a Spanish traditional starter-free cheese made of raw milk and conjugative transfer of tetracycline resistance to lactococci and enterococci. Int. J. Food Microbiol. 2008, 121, 189-194. [CrossRef]

52. Ammor, M.S.; Gueimonde, M.; Danielsen, M.; Zagorec, M.; van Hoek, A.H.A.M.; de Los Reyes-Gavilán, C.G.; Mayo, B.; Margolles, A. Two Different Tetracycline Resistance Mechanisms, Plasmid-Carried tet (L) and Chromosomally Located TransposonAssociated tet (M), Coexist in Lactobacillus sakei Rits 9. Appl. Environ. Microbiol. 2008, 74, 1394-1401. [CrossRef] [PubMed]

53. Mainar, M.S.; Stavropoulou, D.A.; Leroy, F. Exploring the metabolic heterogeneity of coagulase-negative staphylococci to improve the quality and safety of fermented meats: A review. Int. J. Food Microbiol. 2017, 247, 24-37. [CrossRef]

54. Caniça, M.; Manageiro, V.; Abriouel, H.; Moran-Gilad, J.; Franz, C.M. Antibiotic resistance in foodborne bacteria. Trends Food Sci. Technol. 2019, 84, 41-44. [CrossRef]

55. Manyi-Loh, C.; Mamphweli, S.; Meyer, E.; Okoh, A. Antibiotic Use in Agriculture and Its Consequential Resistance in Environmental Sources: Potential Public Health Implications. Molecules 2018, 23, 795. [CrossRef]

56. Finley, R.L.; Collignon, P.; Larsson, D.J.; McEwen, S.A.; Li, X.-Z.; Gaze, W.H.; Reid-Smith, R.; Timinouni, M.; Graham, D.W.; Topp, E. The Scourge of Antibiotic Resistance: The Important Role of the Environment. Clin. Infect. Dis. 2013, 57, 704-710. [CrossRef] [PubMed]

57. Haskell, K.J.; Schriever, S.R.; Fonoimoana, K.D.; Haws, B.; Hair, B.B.; Wienclaw, T.M.; Holmstead, J.G.; Barboza, A.B.; Berges, E.T.; Heaton, M.J.; et al. Antibiotic resistance is lower in Staphylococcus aureus isolated from antibiotic-free raw meat as compared to conventional raw meat. PLoS ONE 2018, 13, e0206712. [CrossRef] [PubMed]

58. Sapkota, A.R.; Hulet, R.M.; Zhang, G.; McDermott, P.; Kinney, E.L.; Schwab, K.J.; Joseph, S.W. Lower Prevalence of AntibioticResistant Enterococci on U.S. Conventional Poultry Farms that Transitioned to Organic Practices. Environ. Health Perspect. 2011, 119, 1622-1628. [CrossRef] [PubMed] 